\title{
Sensitivity of a HIT c-Si Solar Cell to Structural Distortions of the Hydrogenated Amorphous Silicon Constituting the Front Face of the Device
}

\author{
T. Belaroussi ${ }^{1}$, D. Rached ${ }^{1}$, W.L. Rahal2,3,*, F. Hamdache ${ }^{1}$ \\ ${ }^{1}$ Laboratoire de Physique des Plasmas, Matériaux Conducteurs et Leurs Applications, U.S.T.O.M.B. - B.P. 1505, \\ El M’naouar, Oran, Algérie \\ ${ }^{2}$ Laboratoire d'Analyse et d'Application des Rayonnements. U.S.T.O.M.B. - B.P. 1505, El M'naouar, Oran, Algérie \\ ${ }^{3}$ Département de Physique, Faculté des Sciences Exactes et de l'Informatique, Université Abdelhamid Ibn Badis de \\ Mostaganem, Algérie
}

(Received 21 July 2020; revised manuscript received 15 October 2020; published online 25 October 2020)

\begin{abstract}
In this article, we did a comparative study on two different types of high efficiency HIT (Heterojunctions with Intrinsic Thin layers) solar cells: ITO/p-a-Si:H/i-pm-Si:H/n-c-Si/Al and ITO/n-a-Si:H/i-pm-Si:H/pc-Si/Al. The aim is to study the influence of the valence band tail width (characteristic energy $E_{D}$ ) and the conduction band tail width (characteristic energy $E_{A}$ ) of hydrogenated amorphous silicon present as emitter of these solar cells. Our investigations allowed us to conclude that in order to obtain good quality photovoltaic cells, it is important to adjust the different parameters that influence the hydrogenated amorphous silicon distortions used for the development of the HIT cell emitter. On HIT $n$-c-Si solar cell (ITO/pa-Si:H/i-pm-Si:H/ $n$-c-Si/Al), a decrease in $E_{D}$ reduces the recombination rate of the holes in the $p$-a-Si:H layer and thus increases the efficiency of the studied cells. The modification of $E_{A}$ of the conduction band does not influence the quality of the cells. For HIT $p$-c-Si solar cell (ITO/n-a-Si:H/i-pm-Si:H/p-c-Si/Al), the opposite phenomenon occurs. Indeed, a decrease in $E_{A}$ decreases the recombination rate of electrons in the $n$-a-Si:H layer and thus increases the efficiency of the studied cells. The modification of the characteristic energy $E_{D}$ of the valence band does not influence the performance of this type of cells.
\end{abstract}

Keywords: Solar cells, HIT, Hydrogenated amorphous silicon, Characteristic energies, ASDMP, $J-V$ characteristic.

\section{INTRODUCTION}

Efficient and inexpensive solar cells are needed today to meet economic and environmental needs. For this, it is necessary to choose the right photovoltaic devices to improve photovoltaic efficiency [1] and reduce the production costs of these systems. Today, significant scientific and technological progress has been made on silicon HIT (Heterojunction with Intrinsic Thin layer) solar cells because they are a good candidate to increase photovoltaic efficiency and reduce production costs due to the combination of low temperature deposition technology of hydrogenated amorphous silicon a-Si:H and high stable efficiency of crystalline silicon c-Si [2, 3]. The HIT c-Si solar cells are designed from a crystalline silicon substrate c-Si which acts as an active layer on which very thin layers of hydrogenated amorphous silicon (a-Si:H) are deposited.

Hydrogenated amorphous silicon (a-Si:H) is a disordered and defective material. However, an intrinsic a-Si:H layer placed between the emitter and the active layer (a-Si:H/c-Si interface) reduces the unsatisfied bonds on the surface of the absorber (active layer) and then decreases the recombination rate of charge carriers. On the other hand, most of the recombination rate is generated at the emitter, and it is these recombinations which are responsible for the reduction in the current density-voltage $(J-V)$ characteristic produced by the cell.

In this article, we have chosen to study the influence of the valence and conduction band tail widths (characteristic energies $E_{D}$ and $E_{A}$ ) of hydrogenated amorphous silicon present as emitter in the HIT $p$-c-Si solar cell (ITO/n-a-Si:H/i-a-Si:H/p-c-Si/Al) (Fig. 1).

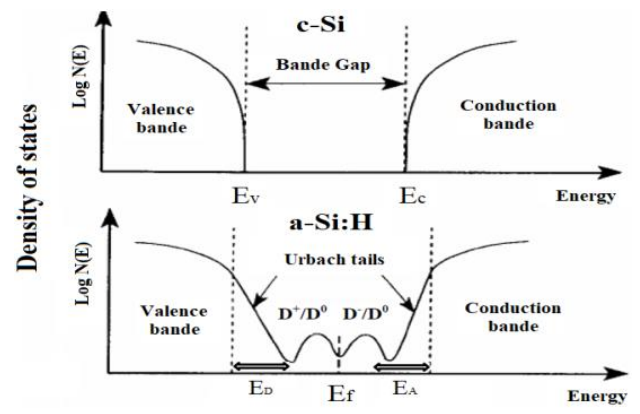

Fig. 1 - Density of states of a-Si:H and c-Si. The characteristic energy $E_{D}$ represents the valence band tail width and the characteristic energy $E_{A}$ represents the conduction band tail width of hydrogenated amorphous silicon

$\mathrm{D}^{-} / \mathrm{D}^{0}$ represents the acceptor-like gap states per unit volume. These states are concentrated in the upper half of the gap of amorphous materials. They gain electrons from the conduction band. It is the number of electrons trapped per unit volume. $\mathrm{D}^{+} / \mathrm{D}^{0}$ represents donor-like gap states per unit of volume. These states are concentrated in the lower half of the gap of amorphous materials. They lose their electrons in the valence band. So, it is the number of holes trapped per unit volume [4]. Experimentally, the $E_{A}$ and $E_{D}$ values are adjusted during the a-Si:H deposition phase on the crystalline silicon substrate.

\footnotetext{
*leila.rahal@univ-mosta.dz
} 
Our objective is to make a comparative study with a previous study which showed that a decrease in the characteristic energy of the valence band tail $E_{D}$ reduces the recombination rate of the holes in $p$-a-Si:H layer on HIT $n$-type c-Si solar cell (ITO/p-a-Si:H/i-pm-Si:H/ $n$-c-Si/Al) and thus increases the efficiency of the studied cells. It has been also shown that the modification of the characteristic energy $E_{A}$ of the conduction band does not influence the quality of the cells [5]. To carry out our research, we have chosen to use the ASDMP software.

\section{INPUT PARAMETERS OF THE STUDIED HIT $p$-c-Si SOLAR CELL}

In this article, the studied solar cell is illustrated in Fig. 2 and has the following structure: indium tin oxide (ITO)/hydrogenated $n$-doped amorphous silicon ( $n$-a-Si:H)/ hydrogenated intrinsic polymorphous silicon (i-pm-Si:H)/ $p$-doped crystalline silicon ( $p$-c-Si)/aluminium (Al).

The parameters of each layer are selected from the literature [6] and summarized in Table 1. All our simulations have been performed under illumination AM 1.5 and at a temperature of $25^{\circ} \mathrm{C}$.

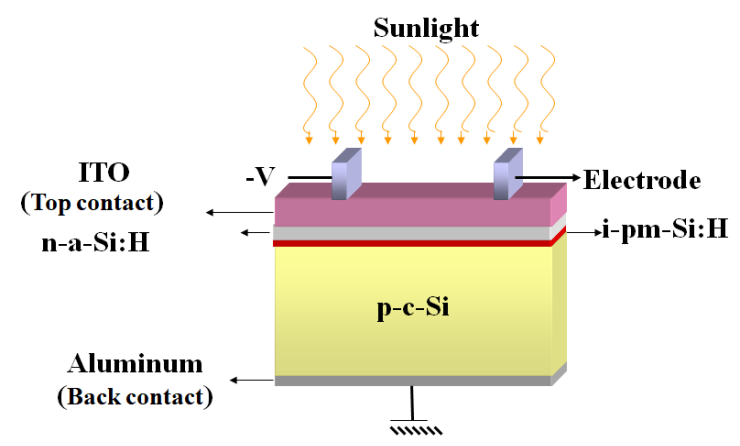

Fig. 2 - Schematic diagram of the HIT $p$-c-Si solar cell

Table 1 - Principal input parameters of HIT $n$-c-Si solar cell

\begin{tabular}{llll}
\hline Parameters & $p$-a-Si:H & i-pm-Si:H & $n$-c-Si \\
\hline$d(\mu \mathrm{m})$ & 0.011 & 0.003 & 300 \\
$\chi(\mathrm{eV})$ & 4 & 3.95 & 4.22 \\
$E_{\mu}(\mathrm{eV})$ & 1.80 & 1.96 & 1.12 \\
$N_{D T O T}, N_{A T O T}\left(\mathrm{~cm}^{-3}\right)$ & $10^{19}$ & $10^{14}$ & $3.10^{11}$ \\
$E_{D}(\mathrm{eV})$ & $0.01-0.09$ & 0.030 & 0.003 \\
$E_{A}(\mathrm{eV})$ & $0.01-0.09$ & 0.030 & 0.003 \\
$G_{D 0}, G_{\mathrm{A} 0}\left(\mathrm{~cm}^{-3} \mathrm{eV}^{-1}\right)$ & $4.10^{21}$ & $4.10^{21}$ & $1.10^{20}$ \\
$\mu_{n}\left(\mathrm{~cm}^{2} / \mathrm{V} \mathrm{s}\right)$ & 20 & 30 & 1000 \\
$\mu_{p}\left(\mathrm{~cm}^{2} / \mathrm{V} \mathrm{s}\right)$ & 4 & 12 & 450 \\
$\phi_{b 0}(\mathrm{eV})$ & 0.12 & & \\
$\phi_{b L}(\mathrm{eV})$ & 1.06 & & \\
\hline
\end{tabular}

\section{SIMULATION MODEL}

The different results were obtained using the ASDMP software (Amorphous Semiconductor Device Modeling Program) developed by Professor Parsathi Chatterjee [7-9] and validated experimentally by Professor Roca's group at École polytechnique de Paris, France. The ASDMP software examines the performance of $p$-i- $n$ and HIT solar cells with data from solar cell performance $[10,11]$ by solving simultaneously Poisson's equation and the continuity equations for free electrons and free holes using finite differences and Newton-Raphson method. These equations are [12]:

$$
\begin{gathered}
\frac{\partial^{2} \psi(x)}{\partial x^{2}}=-\frac{\rho(x)}{\varepsilon}, \\
E=\frac{\partial \Psi(\mathrm{x})}{\partial x} \\
G(x)-R(p(x), n(x)) \boxminus \frac{1}{q} \frac{\partial j_{n(x)}}{\partial x}=0, \\
G(x)-R(p(x), n(x)) \boxminus \frac{1}{q} \frac{\partial j_{p(x)}}{\partial x}=0,
\end{gathered}
$$

where $\Psi(x)$ is the electrostatic potential, $\rho(x)$ is the space charge density in the semiconductor, $\varepsilon(x)$ is the dielectric permittivity of the semiconductor, $J_{n}(x)$ is the electron current, $J_{p}(x)$ is the hole current, $q$ is the electron charge, $G(x)$ is the net optical generation of free electron-hole pairs per unit volume, $R(x)$ is the net recombination of free carriers per unit volume. Equations (3.5)-(3.8) mentioned below represent four boundary conditions for holes and electrons continuity equations:

$$
\begin{gathered}
J_{n}(0)=q S_{n 0}\left[n(0)-n_{0}(0)\right], \\
J_{p}(0)=q S_{p 0}\left[p(0)-p_{0}(0)\right], \\
J_{n}(L)=q S_{n L}\left[n(L)-n_{0}(L)\right], \\
J_{p}(L)=q S_{p L}\left[p(L)-p_{0}(L)\right] .
\end{gathered}
$$

All the equations and approximations were taken from the literature $[4,13-16] . J_{n}(0), J_{n}(L)$ and $J_{p}(0)$, $J_{p}(L)$ represent electron and hole current densities, respectively, at $x=0(\mathrm{TCO} / n)$ and $x=L\left(p /\right.$ metal). $S_{n 0}$, $S_{p 0}, S_{n L}$ and $S_{p L}$ are the surface recombination rates for electrons and holes at these interfaces; $n(0)$ and $p(0)$ represent the densities of electrons and holes at $x=0$; $n(L)$ and $p(L)$ represent the densities of electrons and holes at $x=L$. At $x=0$ and $x=L, n_{0}(0), p_{0}(0)$ and $n_{0}(L)$, $p_{0}(L)$ represent the densities of electrons and holes at thermodynamic equilibrium. To simulate the dangling bond states, the gap-state distributions used in ASDMP model consist of $U$-shaped model and two Gaussian distribution functions. The Urbach tails (or band tails) of the donor and acceptor states are modelled by equations (3.9) and (3.10):

$$
\begin{aligned}
& g_{D T}(E)=G_{D 0} \exp \left[-E / E_{D}\right], \\
& g_{A T}\left(E^{\prime}\right)=G_{A 0} \exp \left[-E^{\prime} / E_{A}\right],
\end{aligned}
$$

where $E$ is measured from $E_{V}, E^{\prime}$ is measured from $E c$, $g$ represents the density of states (DOS, $\mathrm{cm}^{-3} \mathrm{eV}^{-1}$ ).

In the Gaussian model, the distribution of the DOS in the mid-gap is modelled using two Gaussian distributions given by equations (3.11) and (3.12) [4]:

$$
g_{A G}\left(E^{\prime \prime}\right)=\left(\frac{N_{A G}}{\sqrt{2 \pi} \sigma_{A G}}\right) \exp \left\{-\frac{\left(E^{\prime \prime}-E_{A G}\right)^{2}}{2 \sigma_{A G}^{2}}\right\},
$$




$$
g_{D G}\left(E^{\prime \prime \prime}\right)=\left(\frac{N_{D G}}{\sqrt{2 \pi} \sigma_{D G}}\right) \exp \left\{-\frac{\left(E^{\prime \prime \prime}-E_{D G}\right)^{2}}{2 \sigma_{D G}^{2}}\right\},
$$

$E_{A G}$ and $E_{D G}$ represent two Gaussian peak positions, $\sigma_{A G}$ and $\sigma_{D G}$ represent the standard deviation of two Gaussians, the energies $E^{\prime \prime}$ and $E^{\prime \prime \prime}$ are measured, respectively, from the peaks $E_{A G}$ and $E_{D G}$.

In ASDMP model, both specular interference effects and diffused reflectances and transmittances due to interface roughness are taken into account. The front contact barrier height $\phi_{b 0}$ between ITO/n-a-Si:H at $x=0$ is taken equal to $0.12 \mathrm{eV}$ and at the back contact, the barrier height $\phi_{b L}$ between $p$-c-Si/Al is taken equal to $1.06 \mathrm{eV}$ [6].

\section{RESULTS AND DISCUSSION}

In this article, we will study HIT $p$-c-Si solar cells with the following structure: ITO/hydrogenated $n$-doped amorphous silicon (n-a-Si:H)/hydrogenated intrinsic polymorphous silicon (i-pm-Si:H)/p-doped crystalline silicon ( $p$-c-Si)/aluminium (Al). Our goal is to study the effect of the $J=f(V)$ characteristic under illumination on the conduction and valence band tail widths (characteristic energies $E_{A}$ and $E_{D}$ ) of hydrogenated amorphous silicon and then compare the obtained results with the results found with HIT $n$-c-Si solar cells.

Fig. 3 represents the photovoltaic outputs (shortcircuit current density $J_{S C}$, open-circuit voltage $V_{O C}$, fill factor FF and efficiency $\eta$ ) of the ITO/n-a-Si:H/i-pm$\mathrm{Si}: \mathrm{H} / p$-c-Si/Al structure as functions of the conduction band tail width (characteristic energy $E_{A}$ ).

The short-circuit current density $J_{S C}$ is not affected by the variation of the characteristic energy $E_{A}$, since it is mainly dependent on the density of illumination and not on the material used.

Fig. 4 represents the built-in-potential $V_{b i}$ as a function of $E_{A}$. $V_{b i}$ measures the potential difference between $p$ region and $n$ region [2]. We can notice a slight decrease in $V_{b i}$ when we increase $E_{A}$, that is why the open-circuit voltage $V_{O C}$ decreases slightly with the growth of $E_{A}$. However, it is the fill factor FF which is the most sensitive to the variation of $E_{\mathrm{A}}$, thus causing the variation of the efficiency which decreases from $17.44 \%$ for $E_{A}=0.01 \mathrm{eV}$ to $17.24 \%$ for $E_{A}=0.09 \mathrm{eV}$. The fill factor is an important parameter used to qualify the quality of a solar cell. The FF expresses the number of carriers collected. Its decrease implies a low collection of photogenerated carriers which can be explained by a high recombination rate.

Unlike in HIT $n$-c-Si solar cells, where $E_{A}$ does not affect the performance of the cell, in the case of HIT $p$ c-Si solar cells, an increase in $E_{A}$ in the $n$-a-Si:H window layer increases the acceptor-like gap states per unit volume that will have a considerable effect on the quality of the emitter of the studied cells. Indeed, an increase in $E_{A}$ increases the recombination of electrons of the $n$-a-Si:H layer (the number of electrons trapped). To confirm the results obtained, we plotted the variation of the recombination rate as a function of the position in the cell for the two extreme values of the characteristic energy $E_{A}(0.01 \mathrm{eV}$ and $0.09 \mathrm{eV})$.
We can notice from Fig. 5 that the recombination rate increases at the solar cell emitter. It goes from $2.35 \cdot 10^{20} \mathrm{~cm}^{-3} \mathrm{~S}^{-1}$ for $E_{A}=0.01 \mathrm{eV}$ to $2.01 \cdot 10^{21} \mathrm{~cm}^{-3} \mathrm{~s}^{-1}$ for $E_{A}=0.09 \mathrm{eV}$. This confirms the interpretation given above since the efficiency dropped from 17.44 to $17.24 \%$.
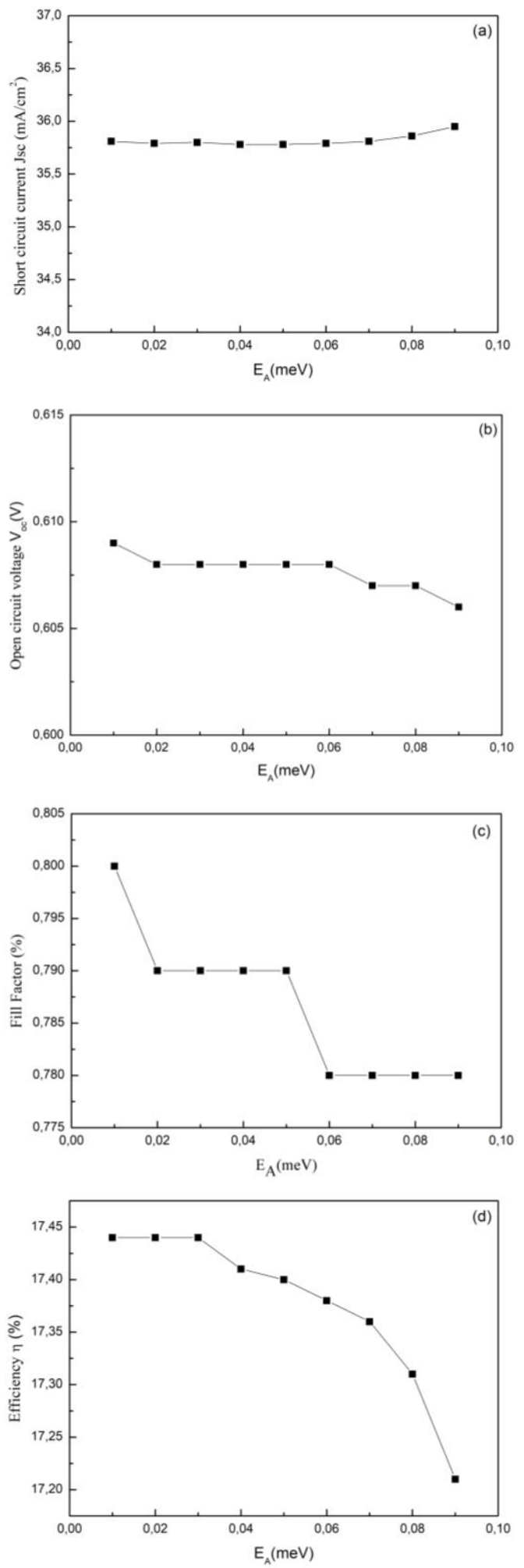

Fig. 3 - Plot of the short-circuit current density $J_{S C}$ (a), opencircuit voltage $V_{O C}(\mathrm{~b})$, fill factor FF (c), and efficiency $\eta$ (d) of HIT $p$-c-Si solar cell as a function of $E_{\mathrm{A}}$ 


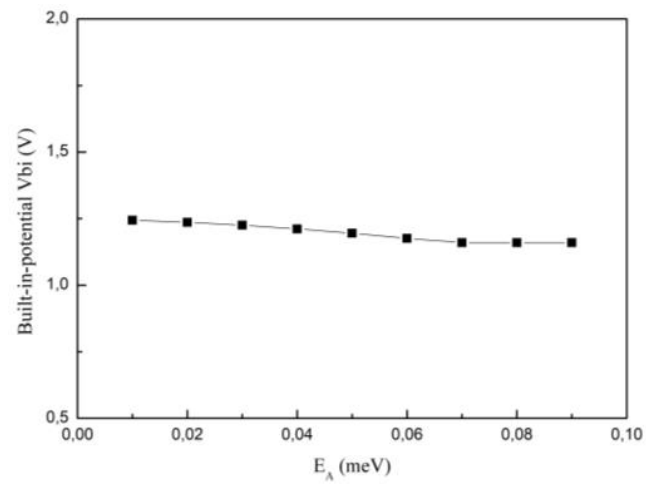

Fig. 4 - Plot of $V_{b i}$ as a function of the characteristic energy $E_{A}=0.01 \mathrm{eV}$ and $0.09 \mathrm{eV}$

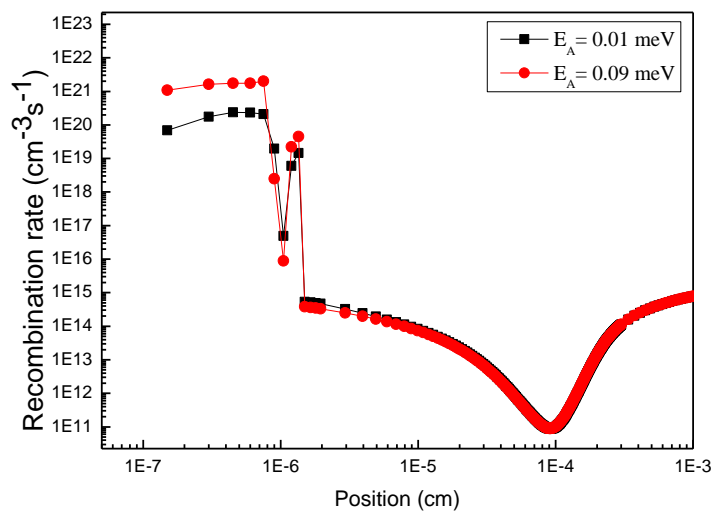

Fig. 5 - The recombination rate as a function of the position in the cell for $E_{A}=0.01 \mathrm{eV}$ and $0.09 \mathrm{eV}$

\section{REFERENCES}

1. M.A. Green, E.D. Dunlop, D.H. Levi, J. Hohl-Ebinger, M. Yoshita, A.W.Y. Ho-Baillie, Prog. Photovolt. Res. Appl. 27 No 7, 565 (2019).

2. K. Bendjebbar, W.L. Rahal, D. Rached, S. Bahlouli, Optik 212, 164741 (2020).

3. F. Azzemou, D. Rached, W.L. Rahal, Optik 217, 164802 (2020).

4. P. Nandita, Energy research unit, Indian association for the cultivation of science: Ph.D. thesis (Jadavpur, Calcutta: India: 2000).

5. W.L. Rahal, D. Rached, J. Nano- Electron. Phys. 9 No 4, 04001 (2017).

6. D. Rached, H. Madani Yssaad, W.L. Rahal, J. Nano- Electron. Phys. 10 No 5, 05012 (2018).

7. S. Chakraborty, A. Datta, M. Labrune, P. Roca i Cabarrocas, P. Chatterjee, EPJ Photovoltaics 4, 40101 (2013).

8. P. Chatterjee, P. Roca i Cabarrocas, AIP Adv. 8 No 1, 015115 (2018).
We have also studied the variation of the characteristic energy $E_{D}$ on the same structure (HIT $p$-c-Si). All the output parameters remain unchanged. The explanation is that an increase in $E_{D}$ increases the acceptor states in the gap which implies an increase in the hole recombination rate of the $n$-a-Si:H layer which does not influence the electron collection.

\section{CONCLUSIONS}

In summary, a comparative study between high efficiency HIT solar cells (HIT $n$-c-Si and HIT $p$-c-Si) had been realized. We studied the influence of the characteristic energies $E_{D}$ and $E_{A}$ of a-Si:H constituting the emitter of these solar cells.

We came to the conclusion that the widths of the band tails have an important influence on the performance of studied solar cells.

Indeed, for HIT $p$-c-Si solar cell (ITO/n-a-Si:H/i-pm$\mathrm{Si}: \mathrm{H} / p-c-\mathrm{Si} / \mathrm{Al})$, a reduction in the characteristic energy of the conduction band tail $E_{A}$ reduces the recombination rate of electrons in the $n$-a-Si:H layer and thus increases the efficiency of this kind of cells. The modification of the energy characteristic $E_{D}$ does not affect the efficiency of the cells.

On HIT $n$-c-Si solar cell (ITO/p-a-Si:H/i-pm-Si:H/ $n$-c-Si/Al), the modification of the energy characteristic $E_{A}$ does not impact the quality of the cells. But a reduction of the characteristic energy of the valence band tail $E_{D}$ reduces the recombination rate of the holes in the $p$-a-Si:H layer and thus increases the efficiency of those solar cells.

9. S. Abolmasov, P. Roca i Cabarrocas, P. Chatterjee, EPJ Photovoltaics 7, 70302 (2016).

10. N. Palit, P. Chatterjee, Sol. Energy Mater. Sol. Cells 53 No 3, 235 (1998).

11. U. Dutta, P. Chatterjee, P. Roca i Cabarrocas, P. Chaudhuri, R. Vanderhaghen, J. Non-Cryst. Solids 338, 677 (2004).

12. D. Rached, M. Mostefaoui, Thin Solid Films 516, 5087 (2008).

13. A. Datta, M. Rahmouni, M. Nath, R. Boubekri, P. Roca i Cabarrocas, P. Chatterjee, Sol. Energy Mater. Sol. Cells 94 No 9, 1457 (2010).

14. M. Nath, P. Chatterjee, J. Damon-Lacoste, P. Roca i Cabarrocas, J. Appl. Phys. 103, 034506 (2008).

15. D. Rached, H.M. Yssaad, Acta Phys. Pol. A 127 No 3767 (2015).

16. M. Rahmouni, S. Belarbi, J. Nano- Electron. Phys. 11 No 2, 02008 (2019).

\title{
Чутливість сонячних елементів c-Si з HIT до структурних спотворень гідро- генізованого аморфного кремнію, що складае фронтальну частину пристрою
}

\author{
T. Belaroussi ${ }^{1}$, D. Rached ${ }^{1}$, W.L. Rahal ${ }^{2,3}$, F. Hamdache ${ }^{1}$ \\ ${ }^{1}$ Laboratoire de Physique des plasmas, Matériaux Conducteurs et leurs Applications, U.S.T.O.M.B. - B.P. 1505, \\ El M'naouar, Oran, Algérie \\ ${ }^{2}$ Laboratoire d'Analyse et d'Application des Rayonnements. U.S.T.O.M.B. - B.P. 1505, El M'naouar, Oran, Algérie \\ ${ }_{3}^{3}$ Département de Physique, Faculté des Sciences Exactes et de l'Informatique, Université Abdelhamid Ibn Badis de \\ Mostaganem, Algérie
}


У статті ми провели порівняльне дослідження двох різних типів високоефективних сонячних елементів з НIT (гетероперехід з власним тонким шаром): ITO/p-a-Si:H/i-pm-Si:H/n-c-Si/Al та ITO/n-a$\mathrm{Si}: \mathrm{H} / \mathrm{i}-\mathrm{pm}-\mathrm{Si}: \mathrm{H} / p$-c-Si/Al. Метою роботи є вивчення впливу ширини хвоста валентної зони (характерна енергія $E_{D}$ ) та ширини хвоста зони провідності (характерна енергія $E_{A}$ ) гідро-генізованого аморфного кремнію, присутнього як випромінювача цих сонячних елементів. Наші дослідження дозволили зробити висновок, що для отримання якісних фотоелементів важливо регулювати різні параметри, які впливають на спотворення гідрогенізованого аморфного кремнію, що використовуеться для розробки випромінювача елементів з НIT. На сонячних елементах $n$-c-Si з HIT (ITO/p-a-Si:H/i-pm-Si:H/n-c-Si/Al) зменшення $E_{D}$ знижуе швидкість рекомбінації дірок у шарі $p$-a-Si:H і тим самим підвищуе ефективність досліджуваних елементів. Модифікація енергії $E_{A}$ зони провідності не впливає на якість елементів. Для сонячних елементів $p$-c-Si з HIT (ITO/n-a-Si:H/i-pm-Si:H/p-c-Si/Al) відбуваеться протилежне явище. Дійсно, зменшення $E_{A}$ зменшуе швидкість рекомбінації електронів у шарі $n$-a-Si:H i, таким чином, збільшуе ефективність досліджуваних елементів. Модифікація характерної енергії $E_{D}$ валентної зони не впливае на продуктивність елементів цього типу.

Ключові слова: Сонячні елементи, НІТ, Гідрогенізований аморфний кремній, Характерні енергії, ASDMP, $J-V$ характеристика. 